\title{
The marine record of the Russell Fiord outburst flood, Alaska, U.S.A.
}

\author{
Ellen A. Cowan, \\ Department of Geology, Appalachian State University, Boone, NC 28608, U.S.A. \\ Paul R. Carlson, \\ U.S. Geological Survey, Menlo Park, CA 94025, U.S.A. \\ Ross D. Powell \\ Department of Geology, Northern Illinois University, DeKalb, IL 60115, U.S.A.
}

\begin{abstract}
The advance of Hubbard Glacier, near Yakutat, Alaska, U.S.A., in spring 1986 blocked the entrance to Russell Fiord with an ice-and-sediment dam, behind which a lake formed. The water level in Russell Lake rose to $25.5 \mathrm{~m}$ a.s.l. The dam catastrophically failed in October 1986, releasing $5.4 \mathrm{~km}^{3}$ of water into Disenchantment Bay. High-resolution seismic-reflection profiles show a $7.5 \mathrm{~km}$ long channel system cut into and buried by glacimarine sediment, represented by continuous, parallel reflections. The chaotic seismic facies filling the channel is interpreted to be debris flow deposits. A gravity core from channel-overbank deposits contained sandy diamicton with mud clasts. Above the channel a $1-2 \mathrm{~m}$ thick sediment drape extends across the bay. Laminated mud, fining-upward sand beds and diamicton were recovered from this unit. The sediment-drape deposits were produced by suspension settling from turbid plumes and non-channelized turbidity currents generated by the outburst flood.
\end{abstract}

\section{INTRODUCTION}

Hubbard Glacier in south-central Alaska, U.S.A., has a history of advances across the narrow mouth of Russell Fiord, closing off that inlet to form a glacier-dammed lake Carlson and others, 1992; Fig. 1). The most recent closure occurred in May 1986. For a 5 month period, an ice-and-sediment dam trapped fresh water in Russell Fiord, forming Russell Lake, the level of which rose to $25.5 \mathrm{~m}$ a.s.l. (Mayo, 1988, 1989). On 7 October 1986, lake water began to seep through crevasses in the $150 \mathrm{~m}$ wide dam, and on that day the dam catastrophically failed, releasing an estimated $5.4 \mathrm{~km}^{3}$ of water during a $30 \mathrm{~h}$ period into Disenchantment Bay (Fig. 1; Mayo, 1988). Mayo (1988) reported that the outburst flood eroded a $300 \mathrm{~m}$ wide swath of alluvial fan and jointed bedrock from the shore near the glacier dam. A flood-water velocity of $11 \mathrm{~m} \mathrm{~s}^{-1}$ was measured in the outburst channel, $4 \mathrm{~h}$ after peak discharge (Mayo, 1989). The momentum of this discharge carried turbulent water $6 \mathrm{~km}$ across Disenchantment Bay where it washed against the terminus of Turner Glacier (Fig. 1). The turbid plume from the Russell Fiord outburst reached the mouth of Yakutat Bay, a distance of $50 \mathrm{~km}$ (Seitz and others, 1986).

This study documents the marine record of this catastrophic flood in Disenchantment Bay. Using highresolution, Huntec deep-tow seismic-reflection profiling,

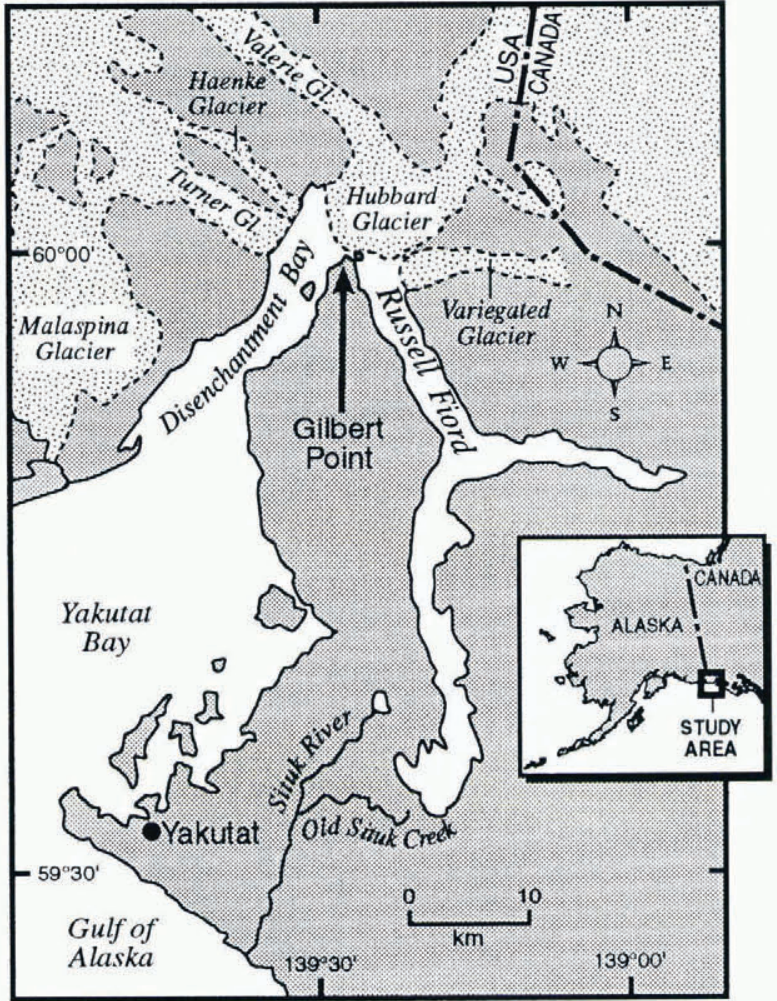

Fig. 1. Location map of Hubbard Glacier, Russell Fiord and Disenchantment Bay. 
$12 \mathrm{kHz}$ echo-sound profiling, and gravity coring we mapped the fjord floor during two cruises on the $\mathrm{R} / \mathrm{V}$ Alpha Helix during 1993 and 1994 (Cowan and others, 1994). Although the flood deposits have been buried since 1986 by glacimarine sediment, they are identified in the sub-surface by seismic profiling and are sampled by coring.

\section{BATHYMETRY OF DISENCHANTMENT BAY BEFORE AND AFTER THE OUTBURST FLOOD}

A total of $155 \mathrm{~km}$ of echo-sound profiles spaced in a $0.5 \mathrm{~km}$ grid was collected during 1993 and 1994 and used to map the bathymetry of Disenchantment Bay (Fig. 2). Navigation was by GPS updated at $30 \mathrm{~s}$ intervals. An isopach map of sediment accumulation (Fig. 3) was drawn by comparing this 1993-94 map with bathymetry charted by the U.S. National Oceanic and Atmospheric Administration during 1978. Errors may be introduced from horizontal positioning of track-lines, tidal variations and the echo-sounder instrument. We estimate that the cumulative error for each isopach is $\pm 1 \mathrm{~m}$.

On a bathymetric map compiled from the 1978 soundings, the contours deeper than $230 \mathrm{~m}$ show a channel that originates on the fjord floor below the entrance to Russell Fiord (see map in Carlson and others (1992)). On

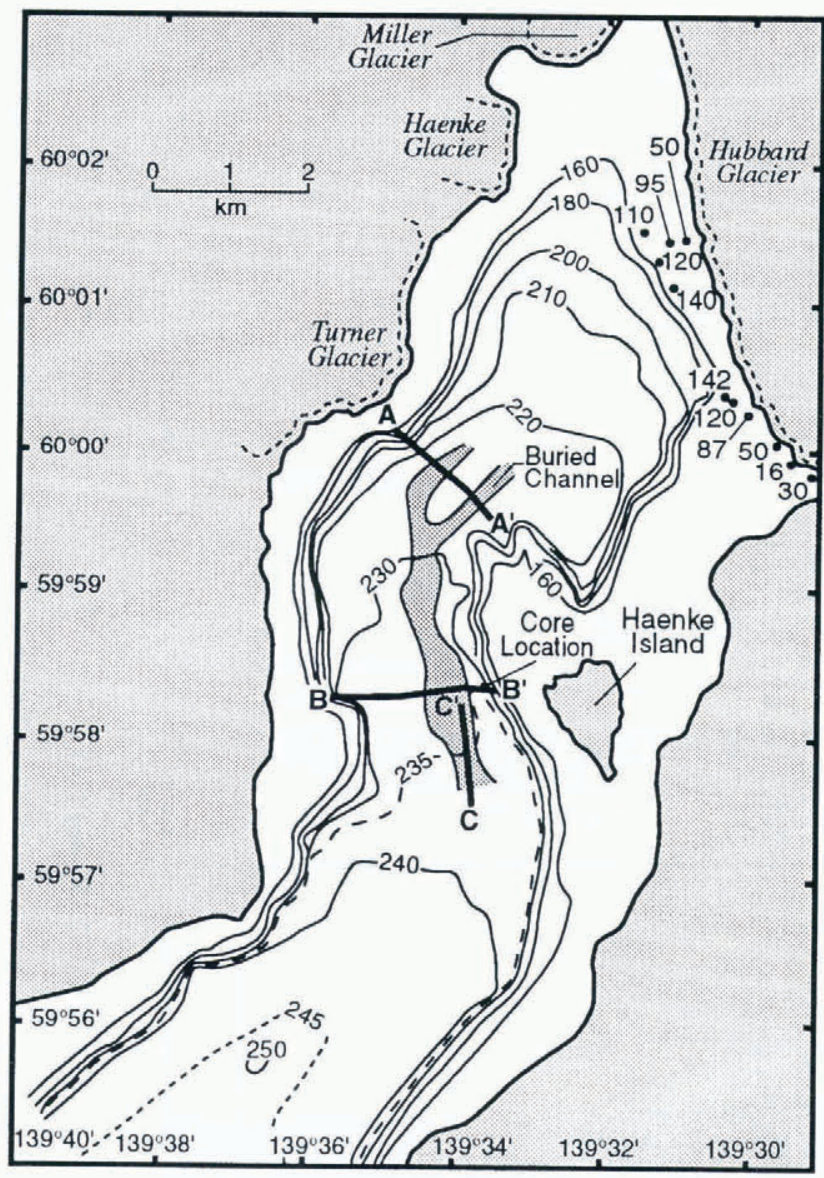

Fig. 2. Balhymetry of Disenchantment Bay in meters during 1993 and 1994 with the outline of the buriedchannel system superimposed. Location of the gravity core and seismic-reflection profiles $A-C$ also shown. Hubbard Glacier terminus as of 6 August 1994 is shown. Spot depths (in meters) were measured on the same day.

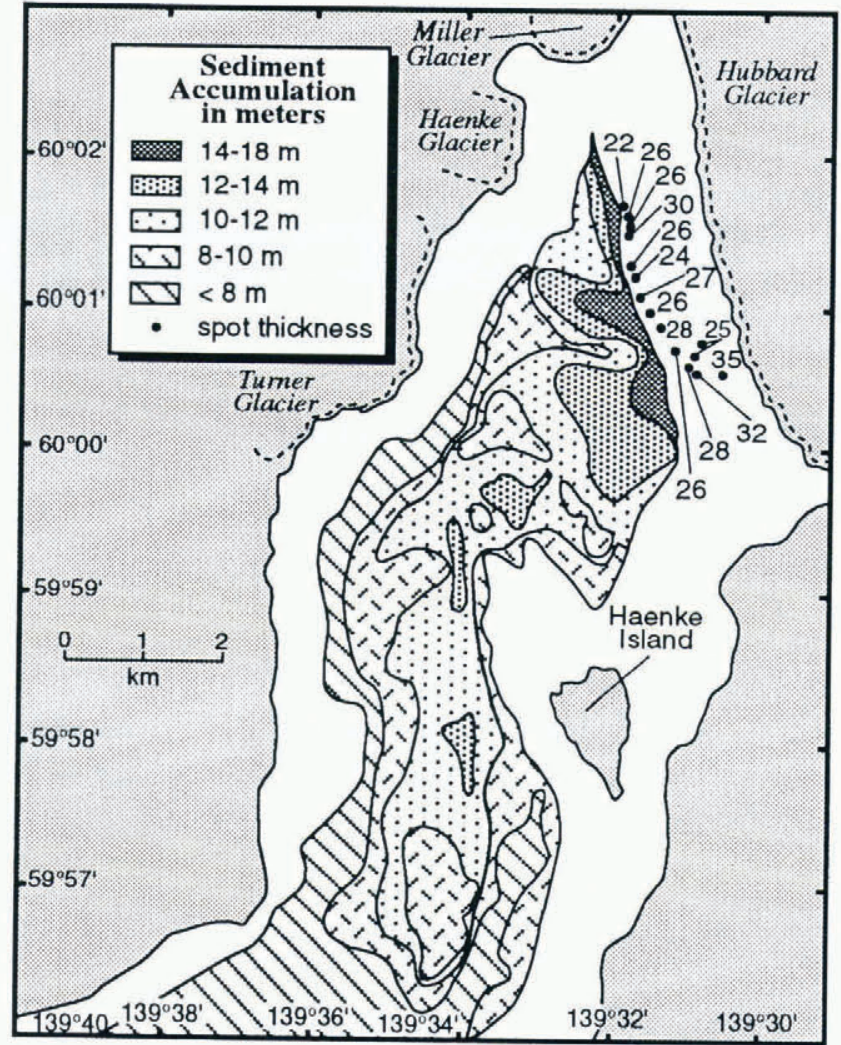

Fig. 3. Isopach map of Disenchantment Bay showing the difference in depths beneath the water surface and the bed between the 1978 NOAA bathymetric survey and this study.

the 1978 map, the channel is not observed at water depths greater than $250 \mathrm{~m}$, toward the southern end of Disenchantment Bay. Contours on the 1993-94 map (Fig. 2) show no evidence of a channel in that location.

A maximum shoaling of $35 \mathrm{~m}$ between 1978 and 1994 was measured near the Hubbard Glacier terminus (Fig. 3) where sediment accumulation is expected to be high because of its proximity to the glacier. During this period, the terminus of Hubbard Glacier experienced both longterm and seasonal advances Krimmel and Trabant, 1992). Failure of the distal side of the morainal bank could result from oversteepening due to rapid sedimentation or glacial advance. Shoaling along the terminus would occur as sediment was deposited by mass movement and sediment-gravity flows.

With distance from Hubbard Glacier terminus, glacimarine sedimentation normally decreases exponentially and consistently (cf. Cowan and Powell, 1991). Therefore, large, irregular areas of high sediment accumulation are interpreted as a product of the outburst flood. For example, between the entrance to Russell Fiord and Haenke and Turner Glaciers 12-18 $\mathrm{m}$ of sediment was deposited Fig. 3). During the outburst flood, surface discharge flowed as a jet across the fjord toward Turner and Haenke Glaciers. Photographs of the outburst flood (as in Seitz and others, 1986) indicate that eddying occurred at the margins of the jet as the sediment-laden flood water mixed with the water in Disenchantment Bay. The thickest sediment accumulation occurs under the apparent axis of the jet, and decreases laterally to less than $8 \mathrm{~m}$ thick. The large, irregular areas of high sediment accumulation downfjord are also thought to 
have resulted from the outburst flood. The thickest sediment accumulation occurs in the center of the fjord, with less than $8 \mathrm{~m}$ deposited on the margins. Elongate areas with sediment accumulation $12-14 \mathrm{~m}$ thick (Fig. 3) coincide with the channel on the 1978 bathymetric map. Sediment accumulation was evidently enough to fill the channel completely, explaining why it does not appear on the 199394 bathymetric map (Fig. 2).

\section{THE BURIED-CHANNEL SYSTEM}

Glacimarine sediment fill consists of variable-amplitude, continuous parallel reflections on the high-resolution seismic-reflection profiles from Disenchantment Bay. The channel system cut into and buried beneath these glacimarine sediments (Fig. 4) is $0.25-0.75 \mathrm{~km}$ in width and $3-7 \mathrm{~m}$ in depth. The channel is filled with a discontinuous chaotic seismic facies that is interpreted as high-viscosity sediment-gravity flow deposits. Two small tributary buried channels begin mid-fjord and join to form one channel $1.5 \mathrm{~km}$ downfjord (Fig. 2). The channel ends south of Haenke Island, after attaining an overall length of $7.5 \mathrm{~km}$.

The channel system was eroded prior to 1978 , probably by turbidity currents originating along the morainal bank in front of Hubbard Glacier. The source of the turbidity currents may have been periodic slumping and failure of the Hubbard Glacier morainal bank as it was built up and oversteepened. This morainal bank was eventually pushed and squeezed by the advancing glacier in 1986 so that its top was above sea level against Gilbert Point where it formed part of the Russell Lake dam (Mayo, 1989; Trabant and others, 1991). During the outburst flood the channel system was completely filled and buried by debris. Since 1986, the channels have not become re-established.
At the head of the buried-channel system, the eastern tributary channel is deeper and better defined than the western channel (Fig. 4). Abrupt truncation of parallel reflections by a discontinuous chaotic fill in the eastern channel indicates erosion of glacimarine sediment by sediment-gravity flows. The channel was probably enlarged by the 1986 outburst flood prior to filling.

The buried channel follows a sinuous course and becomes deeper and wider farther downfjord. The buried channel system contains an estimated $9.6 \times 10^{6} \mathrm{~m}^{3}$ of debris-flow deposits. Channel-fill and overbank deposits are represented on high-resolution seismic-reflection profiles as a chaotic seismic facies similar to the seismic signature of slides and flows observed within other glacimarine settings (Carlson, 1989). In places, the chaotic seismic facies filling the channel extends across the fjord as a wedge. The location of this facies beyond the side of the channel indicates that the sediment-gravity flows overtopped the channel and spread across the fjord floor (Fig. 5). The 1-2 m thick sediment drape above the channel fill is represented on seismic profiles by an opaque to weakly stratified seismic facies extending across Disenchantment Bay. A seismic profile along the channel axis shows that the channel ends abruptly as the chaotic facies thin into parallel continuous reflections to the south (Fig. 6). The $5 \mathrm{~m}$ thick channel fill gradually thins to a $1 \mathrm{~m}$ thick discontinuous deposit that was identified on an additional seismic profile collected perpendicular to the fjord axis $0.5 \mathrm{~km}$ beyond the end of the channel.

Post-flood glacimarine deposits above the channel thin downfjord away from the glacier sources, as expected. In profile $\mathrm{A}-\mathrm{A}^{\prime}, 7 \mathrm{~m}$ of sediment has accumulated above the channel-fill deposits in the northwest near Turner Glacier, and $5 \mathrm{~m}$ has accumulated in the southeast (Fig. 4). In profiles $\mathrm{B}-\mathrm{B}^{\prime}$ and $\mathrm{C}-\mathrm{C}^{\prime}, 4 \mathrm{~m}$ of post-flood accumulation covers the channel fill. Accumulation rates

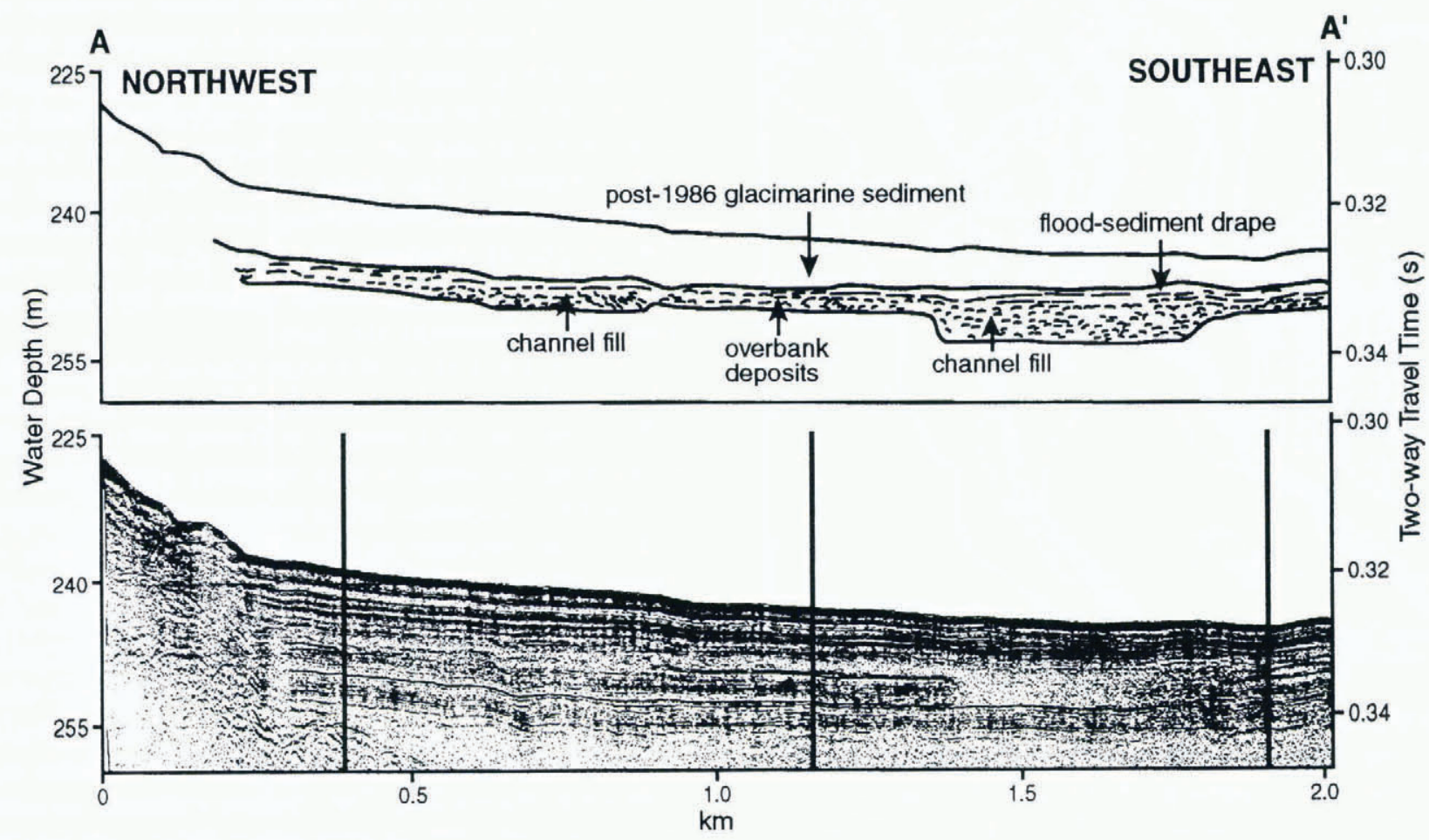

Fig. 4. High-resolution seismic-reflection Profile $A-A^{\prime}$ showing cross-section of main channel and tributary channel. See Figure 2 for location. 


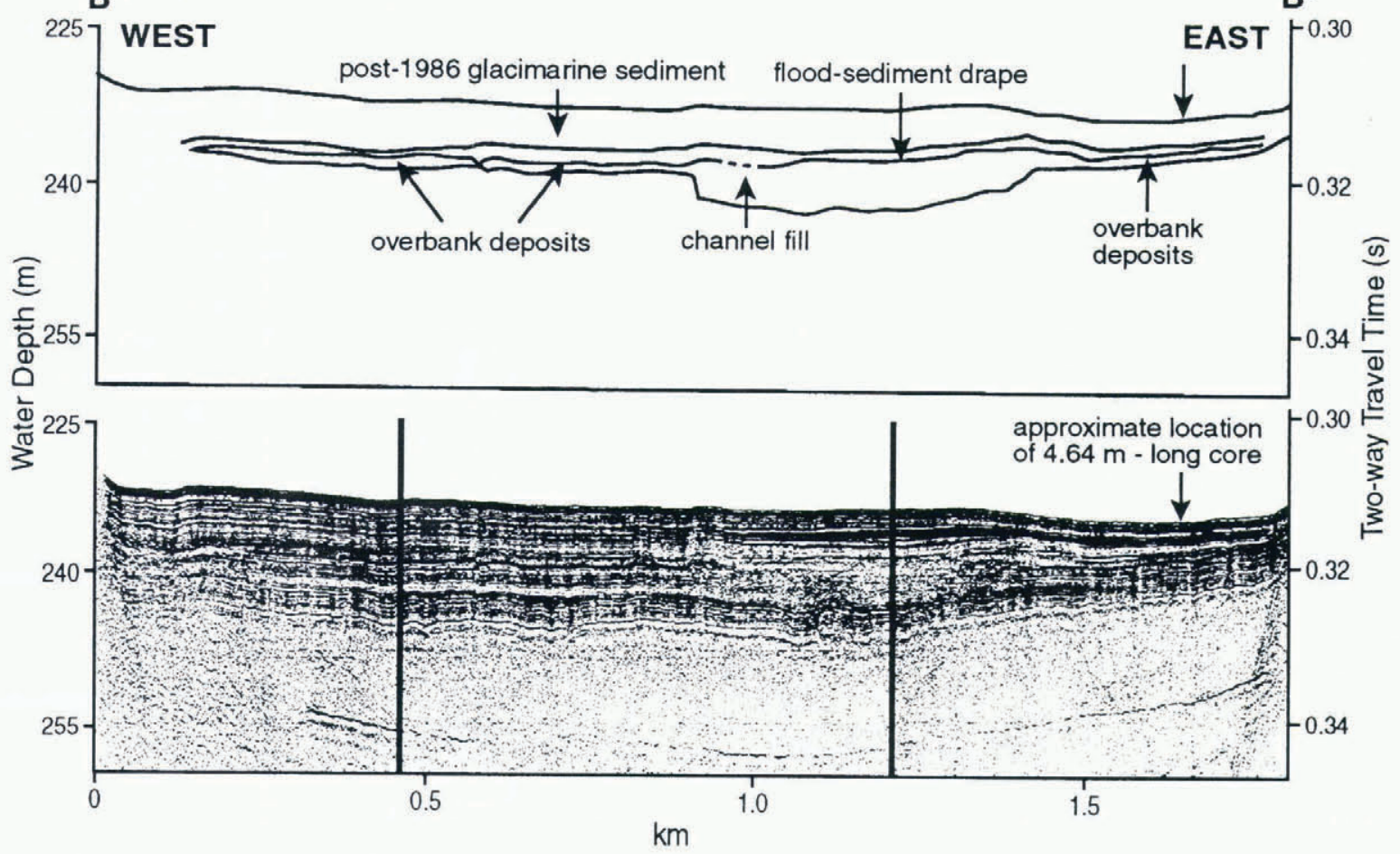

Fig. 5. Profile B-B' showing cross-sectional view of channel and overbank deposits. The core described in this study was collected near this profile (see arrow). See Figure 2 for location.

of $0.9-0.5 \mathrm{~m} \mathrm{year}^{-1}$ are within the range expected for glacimarine sedimentation since the 1986 outburst flood.

\section{LITHOLOGY OF FLOOD DEPOSITS}

Numerous attempts at gravity coring in Disenchantment Bay resulted in the collection of only one core that was sufficiently long to penetrate into the chaotic seismic facies representing the flood deposits (Fig. 2). The $4.64 \mathrm{~m}$ long core was collected near the eastern edge of the channel through flood-drape and channel overbank deposits (Fig. 5). The lower $1.7 \mathrm{~m}$ of this core is interpreted as deposits from the 1986 outburst flood.

The lowest $44 \mathrm{~cm}$ of the core is composed of diamicton Fig. 7) which grades from a massive diamicton (432-

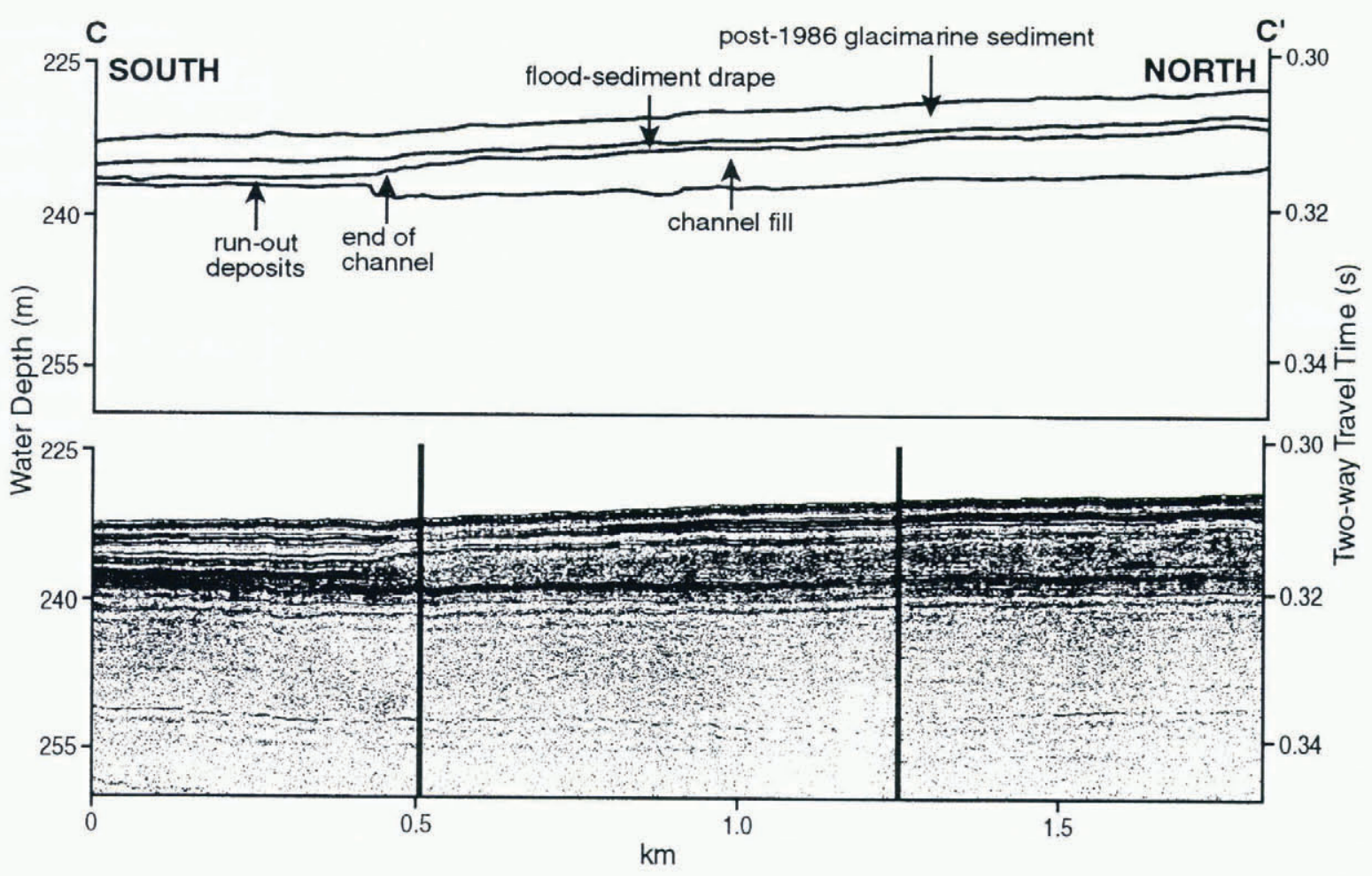

Fig. 6. Distal end of channel shown in Profile $C-C^{\prime}$ where the chaotic channel fill interfingers with seismically stratified glacimarine sediment. 
$464 \mathrm{~cm})$ to stratified sandy diamicton $(420-432 \mathrm{~cm})$. The massive diamicton contains mud clasts up to $10 \mathrm{~cm}$ in diameter, pebbles, and coarse sand lenses. Stratification is produced by concentrated layers of pebbles where long axes are aligned parallel with the bed, alternating with layers of sandy mud. The diamicton coincides with the chaotic seismic facies located above the channel fill. We believe that the diamicton was rapidly deposited by debris flows originating from the outburst moving through the channel. The pebbles and mud clasts were supported within the flow by the fluid matrix formed with clay (Fig. 7). The alternating pebble-rich beds and sandy mud in upper stratified diamicton may have formed by shearing within the debris flow (Hampton, 1975) or from small episodic flow events as the failures decreased in size and number.

The $1.34 \mathrm{~m}$ of flood deposit above the diamictons is a fining-upward sequence of laminated mud interstratified with sand and diamicton beds. It is represented on seismic-reflection profiles as an opaque to weakly stratified seismic facies forming a drape above channelfill and overbank deposits. Immediately above the diamictons is a $4 \mathrm{~cm}$ thick laminated bed with sharp contacts grading from medium sand to very fine sand. As the sand fines upward, silt content increases (Fig. 7). There are several additional graded sand beds up-core. We interpret these as non-channelized turbidity-current deposits because of the presence of sharp basal contacts and medium sand-particle size. The thinly laminated mud is interpreted as a suspension deposit that settled from the turbid plume formed as Russell Lake drained. These cyclopsams and cyclopels consist of planar laminae formed of coarse silt and fine sand alternating with mud. They appear similar to those collected in sediment traps from other high-discharge events in similar temperate glacimarine settings (Cowan and others, 1988). Many laminae are deformed by dropstones rafted from icebergs. Thin diamictons within this laminated sequence were produced from pebbles and sand deposited after rafting by icebergs created when the ice dam collapsed. Diamicton lenses were probably produced when icebergs rolled and dumped their debris to the fjord floor.

\section{DISCUSSION}

More than $150 \mathrm{~m}$ of sediment has accumulated in Disenchantment Bay since deglaciation in the late 19th century. The record of the 1986 outburst flood, the largest known this century, is preserved within the upper $15 \mathrm{~m}$ of this sediment fill. Rapid accumulation of post-flood glacimarine sediment has ensured preservation of the flood deposits, at least until the next advance of Hubbard Glacier along Disenchantment Bay.

A shallow channel system was eroded into the fjord floor prior to the 1986 outburst flood. Given the seismic character of the fjord fill of continuous parallel reflections, these deposits are interpreted as ice-proximal glacimarine. Sediments are unchannelized turbidites, bergstone mud, cyclopsams and cyclopels (Cowan and others, 1994). Sometime prior to the bathymetry undertaken in 1978 , that sedimentary regime changed locally so that erosion

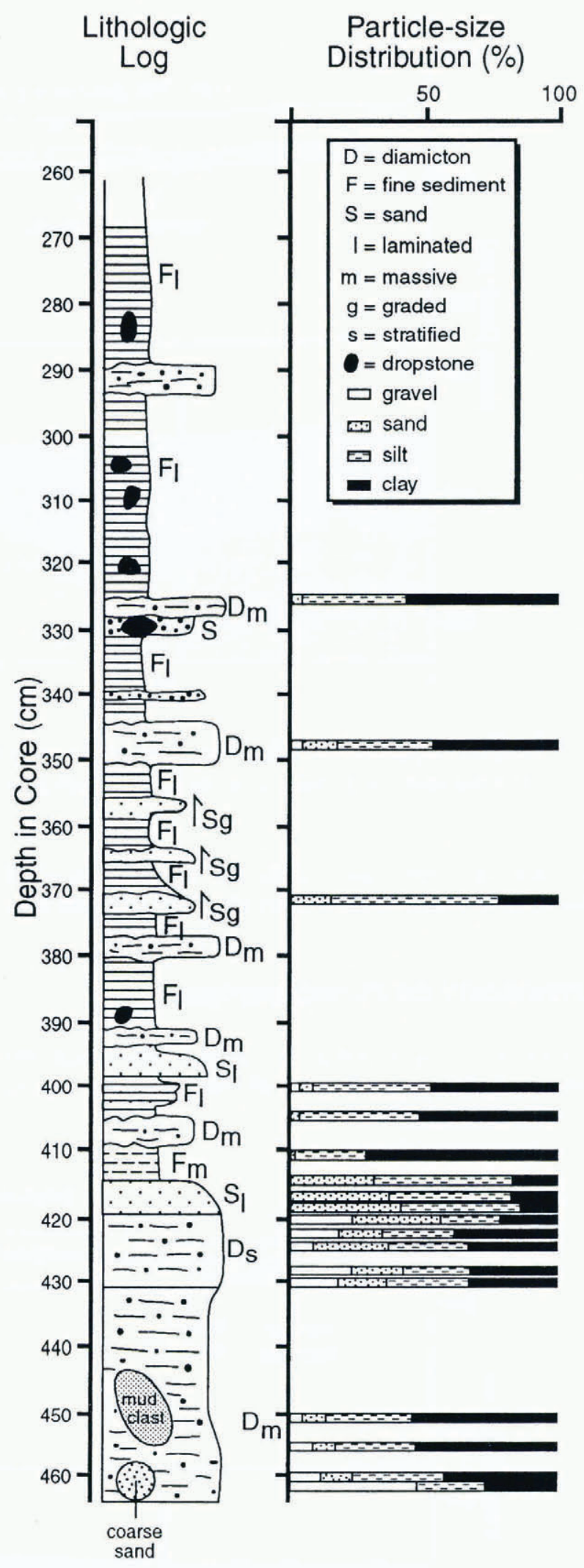

Fig. 7. Lithology and particle-size distribution of lowest $194 \mathrm{~cm}$ of core with flood deposits. Lithology is based on visual core description and $x$-radiographs.

instead of deposition occurred on the fjord floor, forming the channel. Channels are common on the floors of marine-outwash fjords with deltas at the fjord head, but are uncommon in glacial fjords Carlson and others, 1989). A higher foreslope angle is probably important in generating surge-type turbidity currents with sufficient 
energy to erode the sea floor to produce channels (Carlson and others, 1989). We believe that the erosional regime may have been initiated as the morainal bank was oversteepened in front of Hubbard Glacier during the advance. We cannot identify a local source aréa of turbidity-current generation along the Hubbard Glacier morainal bank. However, marine-outwash deltas have similar situations where numerous feeder gullies appear to become localized into a small number of channels (Carlson and others, 1989).

The 1986 flood event was energetic enough to extend the zone of debris-flow deposition into the area of the channels, whereas previous debris flows likely transformed to erosive turbidity currents by the time the flows reached that area. We can identify several sources of sediment that might have initiated debris flows. For example, the subaerial moraine that formed the dam blocking the entrance to Russell Fiord was removed by the outburst flood (Trabant and others, 1991). An alluvial fan that extended 200-300 $\mathrm{m}$ from Gilbert Point into Russell Lake was completely eroded during the first few hours of the flood (Mayo, 1989). These features may have been removed by block failure and sliding which transformed into large debris flows in the channel.

Turbidites and suspension deposits appear as an opaque to weakly stratified seismic facies extending across the floor of Disenchantment Bay above the channel fill. The suspension deposits above the channel fill are thinly laminated sands and muds that result from fluctuations in sediment supply or in velocity of the interflows or overflows transporting the sediment. Evidence of iceberg-rafting in the form of both isolated dropstones and iceberg-rafted diamicton is abundant within the laminated muds deposited from suspension. Debris-laden icebergs were abundant when Hubbard Glacier retreated $500 \mathrm{~m}$ by calving at the entrance to Russell Fiord, as the opening widened and deepened during the flood (Mayo, 1989).

\section{ACKNOWLEDGEMENTS}

This research was funded by U.S. National Science Foundation grants OPP-9223990 to Cowan and OPP-
9223992 to Powell. Additional support was provided by the U.S. Geological Survey Marine Geology Branch. We wish to thank the Captains and crew of the R/V Alpha Helix for their dedication to collection of the seismic profiles and cores. G. B. Standen, Geoforce Consultants provided expertise in collection of high-quality Huntec profiles. The 1993 and 1994 bathymetric data for Disenchantment Bay were analyzed by C. A. Nall. D. Lawson, E. Reimnitz and D. Trabant made helpful comments on the manuscript.

\section{REFERENCES}

Carlson, P. R. 1989. Seismic reflection characteristics of glacial and glacimarine sediment in the Gulf of Alaska and adjacent fjords. Mar. Geol., $85(2-4), 391-416$

Carlson, P. R., R. D. Powell and D. M. Rearic. 1989. Turbidity current channels in Queen Inlet, Glacier Bay, Alaska. Can. 7. Earth Sci. 26 4), 807-820.

Carlson, P. R., R. D. Powell, E. A. Cowan and D. E. Lawson. 1992 Marine geologic investigations of Disenchantment Bay, Alaska, after breakup of 1986 Hubbard Glacier ice dam: $R / V$ harluk Cruise K 1-91YB, 21 -28 June 1991. U.S. Geol. Surv. Open File Rep. 92-706.

Cowan, E. A. and R. D. Powell. 1991. Ice-proximal sediment accumulation rates in a temperate glacial fjord, Southeastern Alaska. Geol. Soc. Am. Spec. Pap. 261, 61-73.

Cowan, E. A., R. D. Powell and N. D. Smith. 1988. Rainstorm-induced event sedimentation at the tidewater front of a temperate glacier. Geology, 16 (5), 409-412.

Cowan, E. A. and 6 others. 1994. Cruise report: $R / V$. Alpha Helix Cruise 173 to western Prince William Sound, Yakutat Bay, and Glacier Bay National Park, northeastern Gulf of Alaska, August 17-September 3, 1993. U.S. Geol. Surv. Open File Rep. 94-258.

Hampton, M.A. 1975. Competence of fine-grained debris flows. $J$. Sediment. Petrol., $45(4), 834844$.

Krimmel, R. M. and D. C. Trabant. 1992. The terminus of Hubbard Glacier, Alaska. Ann. Glaciol., 16, 151-157.

Mayo, L. R. 1988. Advance of Hubbard Glacier and closure of Russell Fiord, Alaska - environmental effects and hazards in the Yakutat area. U.S. Geol. Surv. Circ. 1016, 4-16.

Mayo, L. R. 1989. Advance of Hubbard Glacier and 1986 outburst of Russell Fiord, Alaska, U.S.A. Ann. Glaciol., 13, 189-194.

Seitz, H. R., D.S. Thomas and B. Tomlinson. 1986. The storage and release of water from a large glacier-dammed lake: Russell Lake near Yakutat, Alaska, 1986. U.S. Geol. Surv. Open File Rep. 86-545.

Trabant, D. C., R. M. Krimmel and A. Post. 1991. A preliminary forecast of the advance of Hubbard Glacier and its influence on Russell Fiord, Alaska. U.S. Geol. Surv. Water-Resour. Invest. Rep. 904172 . 